Cooper, P. D. (1955). J. gen. Microbiol. 13, 22-38

\title{
The Site of Action of Penicillin: some Changes in Staphylococcus aureus during the First Two Hours Growth in Penicillin Media
}

\author{
By P. D. COOPER \\ Wright-Fleming Institute of Microbiology, St Mary's Hospital \\ Medical School, London, W. 2
}

\begin{abstract}
SUMMARY: To see whether the initial damage caused by penicillin involved the osmotic barrier, certain characters of Staphylococcus aureus were examined at intervals during the first $2 \mathrm{hr}$. after addition of penicillin to growing cultures. In the $30 \mathrm{~min}$. following addition of penicillin the cell appeared to expose nearly all its reserve penicillin-binding component (PBC), the penicillin uptake being double that which occurred without growth and the reserve PBC disappearing. The amount of PBC in the cell and its rate of exposure to penicillin in excess of normal synthesis (rate of turnover?) were both very small. Between 30 and 60 min. the uptake of $\mathrm{Na}, \mathrm{Mg}, \mathrm{K}, \mathrm{P}$ and increase of total dry matter ceased abruptly. Continued increase in dry wt., while $\mathrm{P}, \mathrm{Na}, \mathrm{Mg}$ and $\mathrm{K}$ decreased slightly, resulted in the penicillintreated cells becoming relatively deficient in these elements. Synthesis of lipid phosphorus and some, but not all, large molecule phosphates still continued, and Fe and Co uptake were not affected. After 60-80 min. water entered and solutes began to leave the cell, and synthesis of large molecule $P$ ceased. The primary site of action of penicillin is probably not concerned with gross assimilation of $\mathrm{Na}, \mathrm{K}, \mathrm{Mg}, \mathrm{P}, \mathrm{Fe}$, Co, or any substance contributing more than $10 \%$ of the dry wt., or with gross synthesis of lipid P. It may, however, involve a reaction turning over $\mathbf{3 0 0 0}$ times while the cell mass is doubled.
\end{abstract}

To describe fully the mode of action of a drug one must account for all the changes which take place from the moment of first contact between cell and drug. Although this is clearly impossible to do in detail, some such attempt is necessary as it is very difficult to pin-point any particular defect as being the cause of death. The specific nature of the penicillin molecule and the small amounts bound by cells suggest that the changes caused by the drug are sequences of events branching from perhaps only one small and specific injury. Each event plays its part in a sequence which culminates in the inability of most of the population to divide, and the relative time of appearance of abnormalities is important.

It was shown elsewhere (Cooper, 1954) that penicillin is firmly bound in a specific manner by a lipid-containing fraction near the cell wall of a sensitive staphylococcus. Believing that the penicillin-binding component (PBC) of sensitive cells (Rowley, Cooper, Roberts \& Lester Smith, 1950) is likely to be the initial site of the bactericidal action of penicillin when acting at its minimal concentration, it was suggested that its presence in this fraction might indicate that the first effect of penicillin is to disorganize some function specific to the cell wall or to the osmotic barrier. To obtain further information on this possibility, penicillin was added to growing cultures of sensitive staphylococci, 
and the following characters were examined very soon after addition of penicillin: $(a)$ the 'phosphate-impermeable volume' (the space enclosed by the osmotic barrier to phosphate) and the volume of the centrifuged cell pad; (b) the dry wt. of the 'lipid particle' fraction, and the phosphate of lipid and other fractions; $(c)$ ability of the cell to take up and retain the elements it requires from the medium. (These abilities may or may not be related to osmotic barrier function for elements other than P.)

The observations described are therefore attempts to obtain some idea of the sequence of defects occurring during the first hour or two after addition of penicillin, paying particular attention to possible cell wall or osmotic barrier activities which might be the site of action of penicillin.

\section{METHODS}

The organism was the penicillin-sensitive (0.02 unit $/ \mathrm{ml}$.) Staphylococcus aureus used previously (Cooper, 1954), which was capable in March 1954 of reproducibly binding penicillin in the resting state to $0 \cdot 90 \pm 0 \cdot 1 \mathrm{unit} / \mathrm{g}$. dry wt. It is interesting that the penicillin-binding capacity of this strain has steadily dropped from 2.4 units/g. in 1949 without concurrent change in penicillin sensitivity or colonial appearance, but the average cell size has increased, so that the number of penicillin molecules bound/cell has not changed. The number of cells/g. dry wt. calculated from viable counts was $8 \times 10^{11}$, but calculations from the average cell diameter $(1 \cdot 3 \mu)$ and specific volume $(c .5 \mathrm{ml} . / \mathrm{g}$.) give about $3.5 \times 10^{12}$ cells/g. dry wt. This figure, itself liable to considerable error, has been used to calculate that about $\mathbf{3 0 0}$ molecules of penicillin are bound per cell in the resting state. The difference from alternative figures for other strains (Maass \& Johnson, 1949 $a$; Eagle, 1954) is probably largely accounted for by the difficulty in assessing the number of cells/g. dry wt., as uptakes in units penicillin/g. dry wt. were often similar.

Groroth conditions. Most of the experiments involved taking serial samples after adding penicillin to a culture growing under standard conditions, with simultaneous samples from a control culture. Tryptic digest agar was inoculated with young cultures, the cells were harvested aseptically after $16 \mathrm{hr}$. at $36^{\circ}$, washed twice with sterile distilled water and the dry matter of the suspension was determined turbidimetrically by reference to a calibration curve. Samples of such suspensions were added to $100 \mathrm{ml}$. warm broth contained in 1 l. long-necked B34 round-bottomed flasks plugged with cotton-wool, so that the final concentrations were $0.2,1.0$ or $2.5 \mathrm{mg}$. $/ \mathrm{ml}$. These were shaken with c. $10 \mathrm{mg}$. of Silicone antifoam A (Hopkins and Williams Ltd.) at about 5 cyc./sec. on a Microid shaker (Griffin and Tatlock Ltd.) at $36^{\circ}$. These conditions gave a mean generation time of about $1 \mathrm{hr}$., which with this organism allowed a good separation in time of many of the metabolic defects caused by penicillin.

Penicillin was generally added $1 \mathrm{hr}$. after inoculation, when the cells were just entering the logarithmic phase, and $10 \mathrm{ml}$. samples, taken at intervals, were rapidly cooled in ice and washed once in distilled water, so that the final 
sample contained less than $1 / 2000 \mathrm{ml}$. medium. Penicillin was usually used in the lowest concentration at which penicillin binding is complete within a minute or two at $37^{\circ}$, i.e. $\mathbf{0 . 1} \mathrm{unit} / \mathrm{ml}$. This concentration is also the lowest at which the rate of bactericidal action is maximal (Eagle, 1951), and at which the production of fresh viable units is immediately stopped (Parker \& Marsh, 1946; and present work). High concentrations may give rise to other less specific effects of penicillin.

Measurement of $P B C$. Assay of $\mathrm{PBC}$ by use of radiopenicillin and the preparation of radiopenicillin were as described by Rowley et al. (1950); radiopenicillin purity was checked by the methods of Cooper, Clowes \& Rowley (1954).

Cell volume. Cell-pad volume was determined by centrifuging $\mathbf{0 . 2 5} \mathrm{ml}$. of cell suspension containing about $0.05 \mathrm{ml}$. of cells for $30 \mathrm{~min}$. at $3500 \mathrm{~g}$ in tubes of $2.5 \mathrm{~mm}$. internal diameter. A mark was made at the top of the cell mass, and the wt. of mercury occupying the volume in the cleaned and dried tubes determined. The phosphate impermeable volume was determined as that volume not penetrated by ${ }^{32} \mathrm{PO}_{4}$, in presence of excess phosphate and carried out rapidly at $0^{\circ}$ so that negligible exchange of ${ }^{32} \mathrm{P}$ could occur between cells and medium. For this, $\mathbf{0 . 2 5} \mathrm{ml}$. of the same cell suspension was added in the cold to $0 \cdot 1 \mathrm{ml}$. of $2 \mathrm{M}$-phosphate at $\mathrm{pH} 7$ containing $0.4 \mu \mathrm{c}$. ${ }^{32} \mathrm{P} / \mathrm{ml}$. After mixing, the suspensions were at once centrifuged for $5 \mathrm{~min}$. at $5000 \mathrm{~g}$ in a refrigerated angle centrifuge using tubes $0.6 \mathrm{~mm}$. internal diameter, and two samples of $0.1 \mathrm{ml}$. of the supernatant were rapidly removed for ${ }^{32} \mathbf{P}$ assay. Samples for 'cell-pad' and 'phosphate impermeable' volumes were thus centrifuged separately at different rates and ionic strengths, and are not comparable with each other. The average cell-pad volume $(6-8 \mathrm{ml} . / \mathrm{g}$.) is high compared with certain other staphylococci $(3 \cdot 47 \mathrm{ml} . / \mathrm{g}$., Gale, 1947; $3 \cdot 61 \mathrm{ml} . / \mathrm{g}$., Mitchell, 1953), but the organism used here was rather larger than average. The data in Fig. 1 suggests that the specific volumes of cells may not be absolute, but probably depend on growth conditions and speeds and ionic strengths obtaining during centrifuging.

Dry matter. Samples of 10-20 mg. cells in weighed $20 \mathrm{ml}$. tubes were dried at $110^{\circ}$ for $16 \mathrm{hr}$., cooled over $\mathrm{P}_{2} \mathrm{O}_{5}$ in vacuo, stoppered and re-weighed.

Phosphorus determinations. Inorganic phosphate was determined by the method of Fiske \& SubbaRow (1925), organic phosphates being first combusted with 'Analytical Reagent' perchloric acid. Cell suspensions were treated with an equal volume of $6 \%$ phenol solution for $20 \mathrm{~min}$. at room temperature to obtain the phenol-soluble phosphates, comprising inorganic $(\mathrm{PhI})$ and organic $(\mathrm{PhO})$ fractions which corresponded quantitatively in normal cells of this staphylococcus with the trichloroacetic acid-soluble (AI and AO) and butanol-soluble phosphates prepared by Mitchell's method (1953). The $\mathrm{PhI}$ in the supernatant was determined directly without combustion and the $\mathrm{PhO}$ was determined as (total phenol-soluble $\mathrm{P}-\mathrm{PhI}$ ). In the whole cells or fractions ${ }^{32} \mathrm{P}$ was assayed by counting samples dried on planchettes, making due allowance for radioactive decay. To determine ${ }^{32} \mathrm{P}$ in the $\mathrm{PhO}, \mathrm{PhI}$ was first precipitated as $\mathrm{NH}_{4} \mathrm{MgPO}_{4}$ by addition to $5 \mathrm{ml}$. samples of $0.1 \mathrm{ml} .20 \mathrm{~N}$-ammonia 
and $0.1 \mathrm{ml}$. of $5 \%(\mathrm{w} / \mathrm{v}) \mathrm{MgCl}_{2}, 5 \mathrm{H}_{2} \mathrm{O}$, leaving $\mathrm{PhO}$ in solution after $16 \mathrm{hr}$. at $4^{\circ}$. Contaminating $\mathrm{PhO}$ in the washed precipitate was less than $5 \% \mathrm{PhI}$. PhI ${ }^{32} \mathrm{P}$ was determined as total phenol-soluble ${ }^{32} \mathrm{P}$ minus $\mathrm{PhO}{ }^{32} \mathrm{P}$. The relative specific activities (' $R$ value', or ratio of observed value of ${ }^{32} \mathrm{P} / \mathrm{P}$ to that value expected at complete equilibration) were expressed as described by Mitchell \& Moyle (1953). The total $P$ and ${ }^{32} \mathrm{P}$ were determined in the residue after phenol treatment, which was taken as representing the large molecule phosphate.

Determination of other elements. Iron was determined as ${ }^{59} \mathrm{Fe}$ and by the thiocyanate colorimetric method. The samples were combusted to $0 \cdot 1 \mathrm{ml}$. with $\mathrm{HClO}_{4}$ and $0.1 \mathrm{ml}$. $10 \%(\mathrm{v} / \mathrm{v}) \mathrm{HNO}_{3}$ and $0.5 \mathrm{ml}$. water were added; the samples were cooled, mixed with $3 \mathrm{ml}$. acetone and $0.5 \mathrm{ml}$. of $20 \%(\mathrm{w} / \mathrm{v})$ $\mathrm{NH}_{4} \mathrm{CNS}$, and made up to $5 \mathrm{ml}$. and the Fe assayed after $30 \mathrm{~min}$. on a Hilger absorptiometer using a blue filter. Sodium, potassium, magnesium and calcium were determined with the Hilger 'Uvispek' photoelectric spectrophotometer using a flame photometer attachment and the quartz prism. Standards contained approximately the same proportions of $\mathrm{Na}, \mathrm{K}, \mathrm{Ca}, \mathrm{Mg}$ and $\mathrm{PO}_{4}$ as found in the samples, and the experimental conditions shown in Table I were used (compare Kapuscinski, Moss, Zak \& Boyle (1952) for Mg and $\mathrm{Ca}$ ). Co was determined as ${ }^{60} \mathrm{Co}$, and by the arc spectrograph.

Viable counts were made by the method of Miles \& Misra (1938).

Table 1. Experimental conditions used for flame photometer assays

Calibration curves for $\mathbf{K}$ and $\mathbf{M g}$ were not linear.

\begin{tabular}{|c|c|c|c|c|c|}
\hline Element & $\begin{array}{c}\text { Wave length } \\
\text { (A) }\end{array}$ & $\begin{array}{c}\text { Minimum } \\
\text { standard } \\
(\mu \text { mole } / \mathrm{ml} .)\end{array}$ & $\begin{array}{l}\text { Min. conc. } \\
\text { determined } \\
(\mu \text { mole } / \mathrm{ml} .)\end{array}$ & $\begin{array}{l}\text { Slit width } \\
\text { (mm.) }\end{array}$ & $\begin{array}{c}\text { Pressure } \mathbf{H}_{2} \\
\text { (lb./sq.in.) }\end{array}$ \\
\hline $\mathbf{N a}$ & 5890 & $0 \cdot 2$ & 0.02 & 0.4 & 1 \\
\hline $\mathbf{K}$ & 7700 & 0.5 & 0.05 & $0 \cdot 6$ & 1 \\
\hline $\mathbf{M g}$ & 3820 & 2 & $0 \cdot 2$ & 0.8 & 2 \\
\hline $\mathrm{Ca}$ & 5540 & 1 & $0 \cdot 1$ & $0 \cdot 6$ & 1 \\
\hline
\end{tabular}

\section{RESULTS}

Changes in cell volume during growth in presence of penicillin

The well-known swelling of organisms in the presence of lethal amounts of penicillin is unaccompanied by increase in cell mass (Fig. 1), and therefore differs from the formation of 'giant forms' in sub-inhibitory titres (e.g. Fleming, Voureka, Kramer \& Hughes, 1950) where increase in cell mass occurs but division is inhibited. Fig. 1 shows a progressive decrease in cell-pad and phosphate-impermeable volumes of normal cells during growth under the conditions used here, and penicillin had very little effect on these volumes up to about $60 \mathrm{~min}$. after its addition. However, soon after the dry matter ceased to increase there was a marked increase in the phosphate-impermeable volume of the cells, and a somewhat smaller increase in the cell-pad volume. The changes in cell-pad volume may reflect changes in cell-packing (perhaps due to changes in mutual adhesiveness) rather than in the volume of individual cells, but the similar nature of the changes in phosphate-impermeable volume 
suggests that this is notso. The important point is that growth in the presence of penicillin causes no rapid collapse in the cell-pad and phosphate-impermeable volumes similar to that produced by addition of butanol or trichloroacetic acid (Mitchell, 1953). About $60 \mathrm{~min}$. after the addition of penicillin, the apparent increase of these volumes without corresponding increase in dry matter suggests that the cells rapidly took up a considerable amount of water. This, with the slow liberation of $\mathrm{PO}_{4}$ and decrease of dry matter which commences soon after, suggests that an increase in the permeability of the osmotic barrier occurs at this stage. Alternatively, the cell wall may become more elastic due to loss of PGP, the polyglycerophosphate complex described by Mitchell \& Moyle (1951b), or some internal breakdown of large molecules may cause a rise in the internal osmotic pressure. Therefore, at most, breakdown of the osmotic barrier's passive properties has only just begun by $60-100 \mathrm{~min}$. after addition of penicillin.
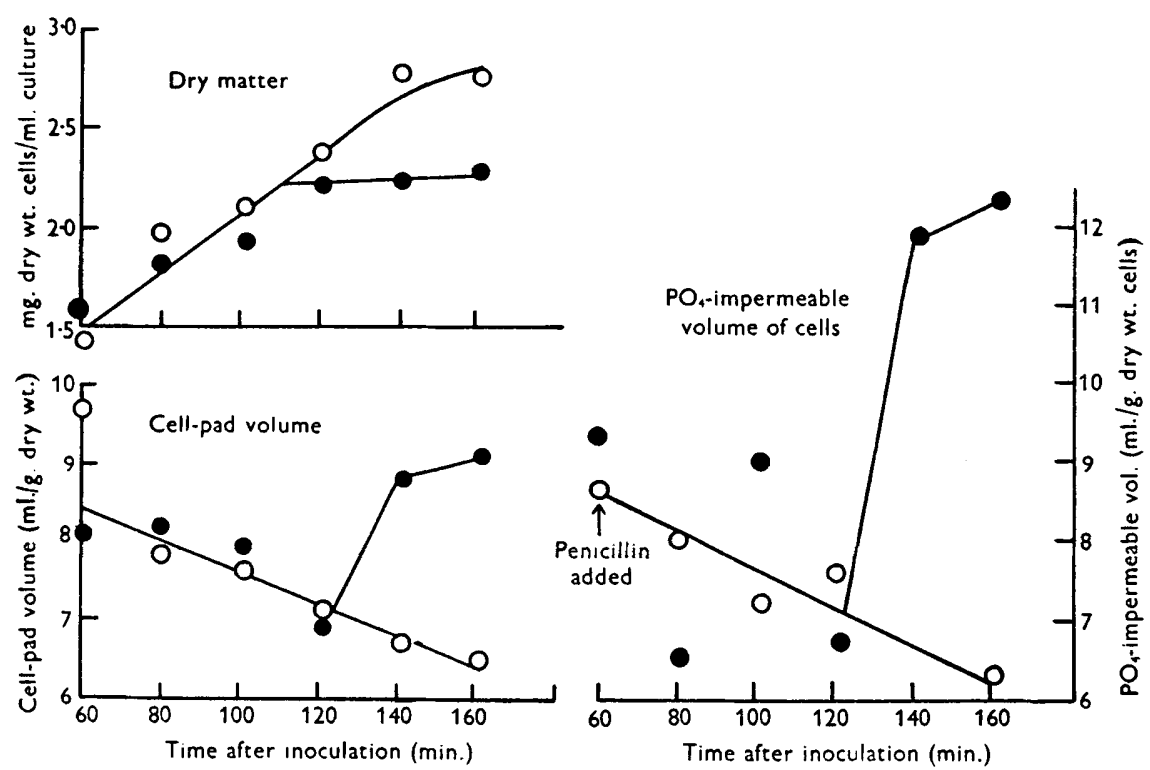

Fig. 1. Changes in cell-pad and phosphate-impermeable volumes of Staphylococcus aureus on growth in the presence of penicillin. The washed cells (equivalent to $1 \mathrm{mg}$. dry wt./ml.) were added to warm shaken broth and penicillin (to $0 \cdot 1 \mathrm{unit} / \mathrm{ml}$.) was added $60 \mathrm{~min}$. later. Samples were taken at intervals. The phosphate-impermeable and cell-pad volumes are not comparable with each other, as different methods of centrifuging were employed. Normal culture, $\mathrm{O} \bigcirc$; penicillin-treated culture,

\section{Changes in cell dry weight}

In agreement with the observations of Parker \& Marsh (1946), $0 \cdot 1$ unit penicillin $/ \mathrm{ml}$. was found to be the lowest concentration at which production of fresh viable units ceased immediately on addition of penicillin. In spite of this, seven separate experiments, including those of Figs. 1 and 4, showed that dry matter increased in identical manner to that of the control for 54-60 min. 
after addition of penicillin, when the increase suddenly ceased. (The fourth 'penicillin' point was low in the dry wt. curve of the experiment shown by Fig. 2.) This was similar to the experience of Park (1951), where increase in turbidity, dry weight, nitrogen, phosphorus or nucleic acid was almost normal for $45 \mathrm{~min}$. after addition of penicillin. This time was very much the same for many experiments, with the exception of one (Table 2), although the control cultures took from 57 to $300 \mathrm{~min}$. to double their weight from the time of adding penicillin. The abruptness of the cessation of the uptake of materials comprising the bulk of the dry matter of the cell, namely carbon and nitrogen compounds, indicates that they all cease to enter the cell at about the same time. The dry matter remained unchanged for a further $60 \mathrm{~min}$. and then gradually decreased.

\section{Table 2. The lack of effect of penicillin on iron uptake}

Washed freshly harvested Staphylococcus aureus cells were added equivalent to $1 \mathrm{mg}$. dry wt. $/ \mathrm{ml}$. to warm broth containing $0.22 \mu \mathrm{mole} \mathrm{Fe} / \mathrm{ml}$. and $0.0025 \mu \mathrm{c}$. ${ }^{59} \mathrm{Fe} / \mathrm{ml}$. at zero time. Penicillin (to $0 \cdot 1$ unit $/ \mathrm{ml}$.) was added $60 \mathrm{~min}$. later. Samples of $10 \mathrm{ml}$. were taken at intervals, cooled and the cells washed twice with broth and once with distilled water, so that ${ }^{59} \mathrm{Fe}$ uptake represents irreversibly bound iron. No difference was found when the broth washing was omitted.

\begin{tabular}{|c|c|c|c|c|}
\hline \multirow{2}{*}{$\begin{array}{l}\text { Period after } \\
\text { inoculation } \\
\quad \text { (min.) }\end{array}$} & \multicolumn{2}{|c|}{$\begin{array}{c}\text { Growth } \\
\text { (mg. bacterial dry } \\
\text { wt./ml. culture) }\end{array}$} & \multicolumn{2}{|c|}{$\begin{array}{l}\text { Bacterial Fe bound } \\
(\mu \mathrm{mole} / \mathrm{ml} . \text { culture })\end{array}$} \\
\hline & Control & + penicillin & Control & + penicillin \\
\hline o & $1 \cdot 0$ & $1 \cdot 0$ & 0 & 0 \\
\hline 30 & $\mathbf{1} \cdot \mathbf{3 3}$ & $1 \cdot 33$ & 0.0070 & $0 \cdot 0066$ \\
\hline 61 & $2 \cdot 32$ & $2 \cdot 39$ & 0.0175 & $0 \cdot 0148$ \\
\hline 80 & $2 \cdot 68$ & $2 \cdot 71$ & $0 \cdot 0245$ & $0 \cdot 0260$ \\
\hline 103 & $3 \cdot 68$ & $2 \cdot 85$ & $0 \cdot 0400$ & 0.0396 \\
\hline 122 & $3 \cdot 86$ & $2 \cdot 89$ & 0.0446 & $0 \cdot 0418$ \\
\hline 142 & $4 \cdot 12$ & $2 \cdot 99$ & 0.0526 & $0 \cdot 0526$ \\
\hline 162 & $4 \cdot 13$ & $\mathbf{2 \cdot 8 6}$ & 0.0549 & $0 \cdot 0549$ \\
\hline 180 & $4 \cdot 29$ & $2 \cdot 91$ & $0 \cdot 0637$ & 0.0583 \\
\hline
\end{tabular}

\section{Changes in elementary composition}

If PBC were itself the 'shuttle' by which a medium constituent is transported into the cell, the entry of this constituent should be rapidly stopped by penicillin above $0 \cdot 1 \mathrm{unit} / \mathrm{ml}$. If so, the constituent is not glucose (or oxygen) as the oxidation of this substance is unaffected by growth for at least $1 \mathrm{hr}$. in penicillin (Gale \& Paine, 1951) and penicillin is still active anaerobically (see below). It is not an organic substance other than glucose, as penicillin is equally effective on media from which these are missing (Hunter \& Baker, 1949; Grelet, 1949). This leaves only the inorganic constituents. Although $P$ uptake is known to be an active function of the osmotic barrier in the staphylococcus used by Mitchell (1953), little is known of the uptake mechanism for $\mathrm{K}, \mathrm{Na}$, or $\mathrm{Mg}$. Even so, it would be interesting to see whether the uptake of these metals is affected by penicillin.

Fig. 2 and Table 4 show that the increase of total dry wt. and the uptake of $\mathrm{P}, \mathrm{K}, \mathrm{Na}$ and $\mathrm{Mg}$ stopped quite abruptly at intervals after addition of 
penicillin which did not quite coincide, so that when dry wt. increase had ceased the cells were relatively somewhat deficient in these elements. Usually some loss of these elements started soon after dry wt. ceased to increase.

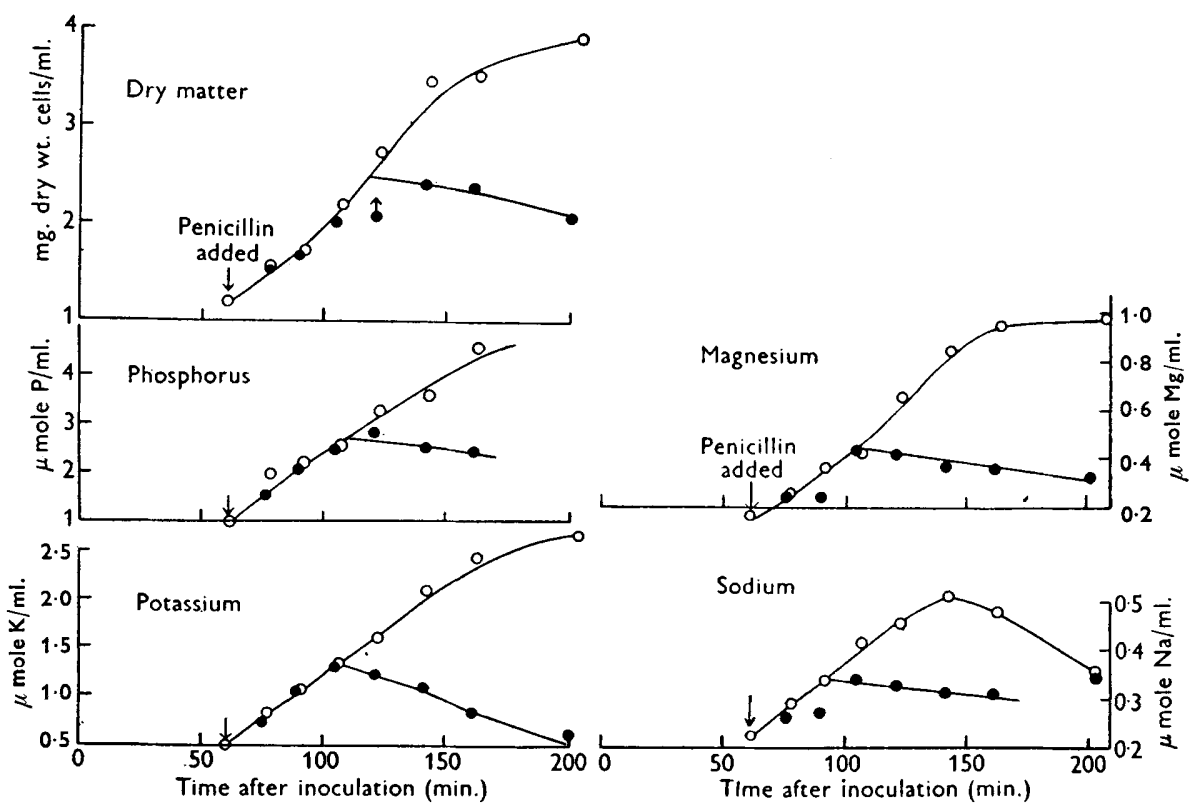

Fig. 2. Changes in elementary composition of Staphylococcus aureus growing in presence of penicillin. Conditions as for Fig. 1. Values refer to quantities of element in cells/ml. culture.

Table 3. Effect of $0 \cdot 1$ unit penicillin/ml. on ${ }^{60} \mathrm{Co}$ uptake

Uptake is expressed as $\mu \mathrm{c}$. bacterial ${ }^{60} \mathrm{Co} / \mathrm{l}$. culture, as accurate assays of $\mathrm{Co}$ in cells and medium were not available. Cells contained about $5 \mu \mathrm{g}$. Co/g. dry wt., medium about $0.2 \mu \mathrm{g}$. Co/ml. To each of four $100 \mathrm{ml}$. shake-cultures $4 \mu \mathrm{c}$. of ${ }^{60} \mathrm{Co}$ were added $65 \mathrm{~min}$. after addition of cells equivalent to $1 \mathrm{mg} . / \mathrm{dry} \mathrm{wt} . / \mathrm{ml}$. Penicillin was added to the three test cultures, 60, 75 and $115 \mathrm{~min}$. after inoculation.

\begin{tabular}{|c|c|c|c|c|}
\hline \multirow[b]{2}{*}{$\begin{array}{l}\text { Period after } \\
\text { inoculation } \\
\quad \text { (min.) }\end{array}$} & \multicolumn{4}{|c|}{$\mu$ c. bacterial ${ }^{60} \mathrm{Co} / \mathrm{l}$. culture } \\
\hline & Control & $\begin{array}{c}\text { Penicillin } \\
\text { added at } \\
60 \mathrm{~min} .\end{array}$ & $\begin{array}{c}\text { Penicillin } \\
\text { added at } \\
75 \text { min. }\end{array}$ & $\begin{array}{l}\text { Penicillin } \\
\text { added at } \\
115 \text { min. }\end{array}$ \\
\hline 65 & $\mathbf{0}$ & 0 & $\mathbf{0}$ & 0 \\
\hline 80 & $0 \cdot 326$ & $0 \cdot 428$ & $0 \cdot 320$ & $0 \cdot 326$ \\
\hline 107 & $0 \cdot 376$ & $0 \cdot 508$ & $0 \cdot 388$ & 0.376 \\
\hline 131 & $0 \cdot 356$ & $0 \cdot 608$ & $0 \cdot 360$ & 0.424 \\
\hline 156 & $0 \cdot 400$ & 0.522 & $0 \cdot 348$ & $0 \cdot 408$ \\
\hline 185 & $0 \cdot 396$ & $0 \cdot 444$ & - & $0 \cdot 308$ \\
\hline 208 & $0 \cdot 326$ & $0 \cdot 416$ & $0 \cdot 292$ & $0 \cdot 282$ \\
\hline
\end{tabular}

'Uptake' of iron was not affected by penicillin, and cobalt 'uptake' was not inhibited but was sometimes stimulated slightly (Tables 2 and 3). The 'uptake' of $\mathrm{Fe}$ and of Co measured here differ from the uptakes of $\mathrm{P}, \mathrm{K}, \mathrm{Na}$ and $\mathbf{M g}$ in 
that they include any equilibration between cell and medium. $\mathrm{Ca}$, rather surprisingly, was present in the washed cells in amounts too small to measure accurately by the method used.

Table 4 also shows the mean elementary composition of the staphylococcal cells during logarithmic growth. The values for $\mathbf{P}$ and $\mathbf{K}$ were fairly constant over the growth period in the control cells, but the $\mathrm{Na}$ content rose to a peak during most active growth and fell towards the end of the logarithmic phase. The $\mathrm{Fe}$ and $\mathrm{Mg}$ content increased by approximately $70 \%$ of the initial value. Allowing for incomplete packing, the cells probably occupy about $5 \mathrm{ml} . / \mathrm{g}$. of the cell-pad volume of $7.5 \mathrm{ml}$./g. It is interesting that the cells contain more $\mathrm{P}, \mathrm{K}, \mathrm{Fe}$ and Co per unit volume than the medium, but less $\mathrm{Na}, \mathrm{Mg}$ and $\mathrm{Ca}$ (unless some is lost in the washing process).

\section{Changes in phosphate distribution}

Fig. 2 shows that the net gain of $\mathrm{PO}_{4}$ from the medium was not affected by penicillin until just before the increase in dry matter ceased. Fig. 3 shows that the accumulation of $\mathbf{P}$ in the $\mathrm{PhI}$ and $\mathrm{PhO}$ stopped about the same time as, or earlier than, the assimilation of total $P$. In no experiment was there any sign of the $\mathrm{PhO}$ (nucleotide?) fraction increasing above that of control. However, net synthesis of the large molecule $\mathbf{P}$ (polyglycerophosphate complex (PGP) + deoxyribonucleic acid (DNA) + ribonucleic acid (RNA) + lipid phosphate) continued at the expense of the $\mathrm{PhO}$, but at a slower rate. This suggests that one or more component has ceased to be formed, possibly PGP (Mitchell \& Moyle, 1950) as no accumulation of nucleotides suggesting inhibition of nucleic acid synthesis was found. Very little $\mathbf{P}$ was lost from the cells until about $90 \mathrm{~min}$. after uptake ceased. Fig. 3 suggests that the cessation of $P$ uptake is due to an interference with the transport mechanism, as otherwise a considerable and lasting accumulation of $\mathbf{P}$ in the $\mathrm{PhI}$ would be expected when uptake ceased. The alternative possibility, that $\mathrm{PO}_{4}$ continues to enter the cell's inorganic phosphate pool but in a loosely bound form which was completely washed out between harvesting and assay, is unlikely as Fig. 3 shows that there is still a considerable pool of $\mathrm{PhI}$ and $\mathrm{PhO}$ phosphates which are not washed out.

Comparison of the rates of entry of ${ }^{32} \mathrm{P}$-labelled phosphate into the various fractions (expressed as relative specific activities, or ' $R$ ' values, in Table 5) shows that the specific activity of the total $P$ stayed constant at the value occurring as the time uptake ceased, so that there was no exchange between cell and medium after this time. Thus, the active uptake mechanism did not continue simultaneously with an equivalent loss from say, PGP, where $\mathbf{P}$ is not known definitely to enter via the inorganic pool. Nevertheless, there were marked rearrangements in the internal distribution of $P$. The $R$ value of the $\mathrm{PhI}$ rose more rapidly than the control initially, then dropped to very low values, while those of the $\mathrm{PhO}$ and large molecule $\mathbf{P}$ were practically constant for several hours. Mitchell \& Moyle (1953) said that it is not known whether the lipid phosphate and PGP are derived from the phosphate of the medium (mI) or the shuttle compound which transports the phosphate across the 


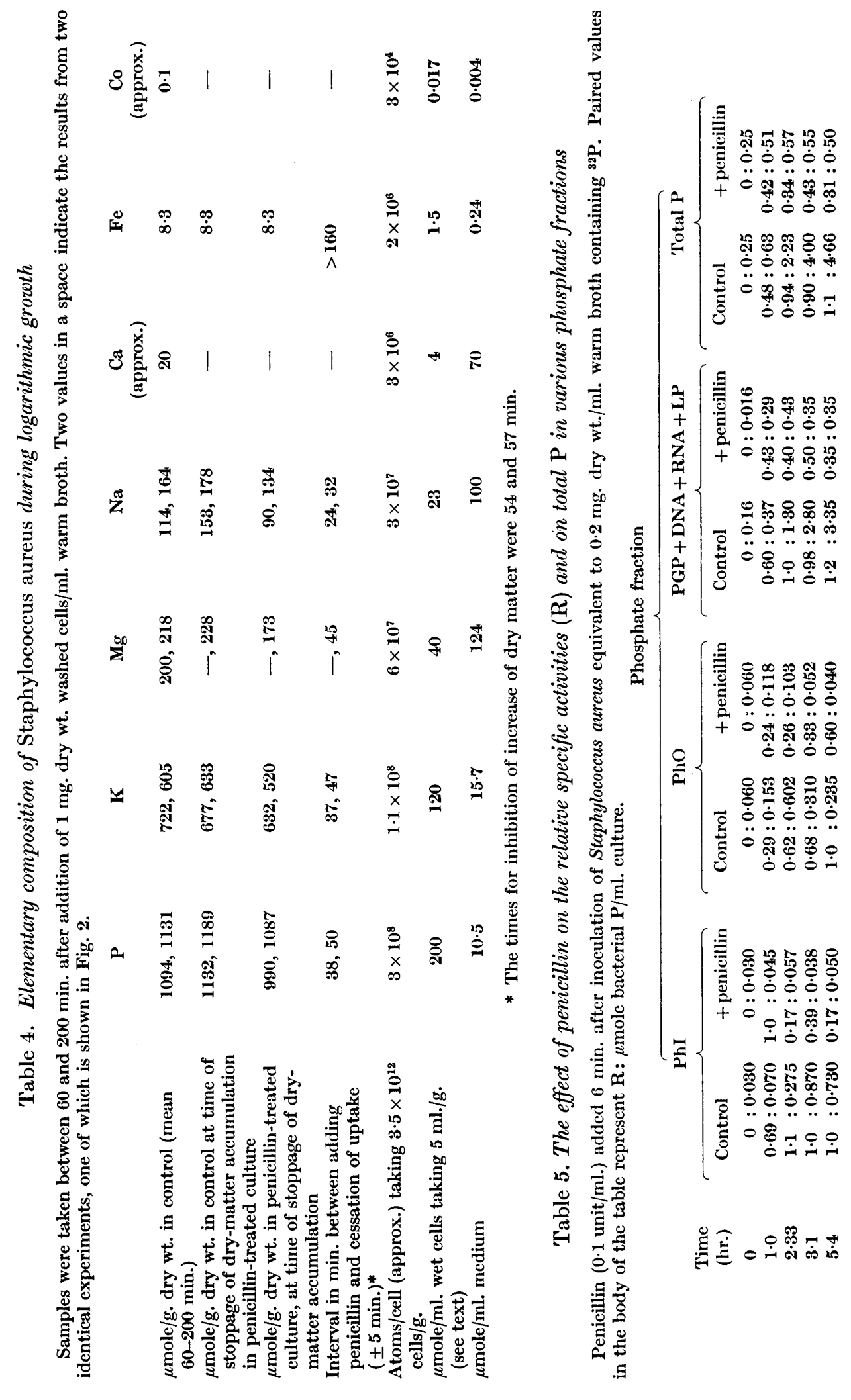


osmotic barrier without turnover, or from AI with turnover. The lack of exchange of ${ }^{32} \mathrm{P}$ between cell and medium after net uptake was stopped by penicillin is evidence that either $(a)$ significant PGP synthesis directly from $\mathrm{mI}$ has also ceased by the time the $\mathbf{P}$ transport has stopped, or $(b)$ all $\mathbf{P}$ enters via the one transport mechanism, and $\mathbf{P}$ for $\mathbf{P G P}$ comes via $\mathbf{A I}$ with turnover, i.e. reversibly. The lack of effect of penicillin on the $P$ uptake until 50-60 min.

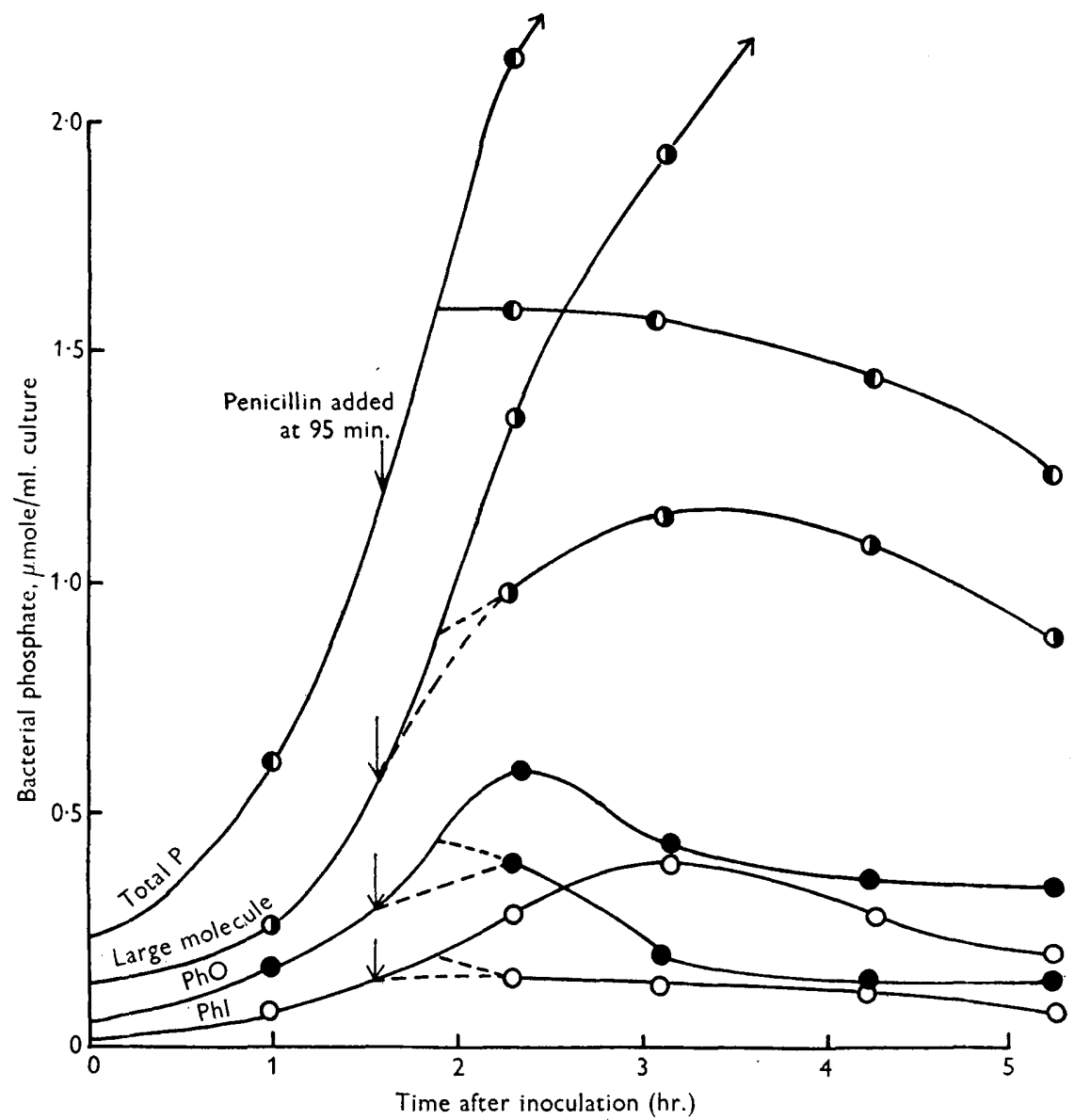

Fig. 3. Changes in the distribution of phosphate between the various fractions of Staphylococcus aureus on growth in presence of penicillin. Cells equivalent to $0.2 \mathrm{mg}$. dry wt. $/ \mathrm{ml}$. were added to warm shaken broth and penicillin to $0.1 \mathrm{unit} / \mathrm{ml}$. was added 95 min. later. $(O-O)=$ PhI, $(\bullet-\bullet)=\mathrm{PhO},(\odot-O)=$ 'large molecule phosphate', $(\mathbf{0}-\mathbf{0})=$ total phosphate. In each case the upper curve is the control.

after the addition of penicillin suggests that the $\mathbf{P}$ for PGP (comprising nearly $40 \%$ of the total cell $\mathrm{P}$, Mitchell \& Moyle, $1951 b$ ) cannot be derived directly from the medium, and at the same time cease to enter PGP much before the total $\mathbf{P}$ uptake ceases. This means that the statement of Mitchell \& Moyle (1950) that the PGP content falls very rapidly after addition of penicillin is also evidence for $(b)$ above. The changes in specific activity shown in Table 5 
suggest that the synthesis of some component(s) of PGP + DNA + RNA + LP, presumably PGP, is inhibited within $60 \mathrm{~min}$. by penicillin, but the reverse loss back into the PhI is still allowed. Table 6 shows that synthesis of total lipid $\mathbf{P}$ continued after accumulation of dry matter had ceased. Growth in 0.1 unit penicillin $/ \mathrm{ml}$. for $1 \mathrm{hr}$. did not affect the proportion by weight of the 'lipid particle' fraction sedimenting between 5000 and $12,000 \mathrm{~g}$.

Table 6. Effect of penicillin on lipid phosphorus of growing

Staphylococcus aureus cells

Fifty $\mathrm{ml}$. of overnight culture were added to $300 \mathrm{ml}$. of warm broth in each of 14 Roux bottles, and penicillin ( $0.06 \mathrm{unit} / \mathrm{ml}$.) was added to 7 bottles $0.66 \mathrm{hr}$. after inoculation. The contents of one control and one penicillin-treated bottle were harvested at different times during incubation at $36^{\circ}$, washed twice and assayed for lipid $\mathbf{P}$.

\begin{tabular}{|c|c|c|c|c|c|c|}
\hline \multirow[b]{2}{*}{$\begin{array}{c}\text { Time after } \\
\text { inoculation } \\
(\mathrm{hr} .)\end{array}$} & \multicolumn{3}{|c|}{ Control culture } & \multicolumn{3}{|c|}{ Penicillin-treated culture } \\
\hline & $\begin{array}{l}\text { Viable count } \\
\text { orgs. } / \mathrm{ml} . \\
\text { culture } \times 10^{6}\end{array}$ & $\begin{array}{l}\text { Dry wt. cells, } \\
\mu \mathrm{g} . / \mathrm{ml} \text {. culture }\end{array}$ & $\begin{array}{c}\text { Bacterial } \\
\text { lipid } \mathbf{P}, \\
\mu \text { mole } \mathbf{P O} \\
\text { culture }\end{array}$ & $\begin{array}{l}\text { Viable count } \\
\text { orgs. } / \mathrm{ml} . \\
\text { culture } \times 10^{6}\end{array}$ & $\begin{array}{l}\text { Dry wt. cells, } \\
\mu \mathrm{g} . / \mathrm{ml} . \text { culture }\end{array}$ & $\begin{array}{c}\text { Bacterial } \\
\text { lipid } \mathbf{P}, \\
\mu \text { mole } \mathbf{P O} \\
\text { culture }\end{array}$ \\
\hline $0 \cdot 8$ & $\mathbf{2} \cdot \mathbf{2}$ & 10 & $0 \cdot 83$ & $\mathbf{2 \cdot 2}$ & $8 \cdot 6$ & $0 \cdot 81$ \\
\hline $\mathbf{1 . 9}$ & $8 \cdot 8$ & $48 \cdot 7$ & $\mathbf{1} \cdot \mathbf{3 2}$ & $7 \cdot 1$ & $26 \cdot 2$ & $1 \cdot 47$ \\
\hline $\mathbf{2 \cdot 8}$ & 16 & $68 \cdot 4$ & $1 \cdot 71$ & 1 & $26 \cdot 2$ & 0.73 \\
\hline $\mathbf{3 \cdot 9}$ & 38 & $87 \cdot 7$ & $2 \cdot 02$ & $0 \cdot 4$ & $20 \cdot 7$ & $1 \cdot 43$ \\
\hline $5 \cdot 0$ & 46 & 119 & $2 \cdot 26$ & $0 \cdot 3$ & $23 \cdot 1$ & $\mathbf{1} \cdot \mathbf{5 9}$ \\
\hline $5 \cdot 9$ & 62 & 135 & $\mathbf{2 \cdot 8 4}$ & $0 \cdot 4$ & $17 \cdot 6$ & $0 \cdot 65$ \\
\hline $6 \cdot 9$ & 78 & 186 & $\mathbf{3 \cdot 3 5}$ & 0.4 & $16 \cdot 5$ & $0 \cdot 66$ \\
\hline
\end{tabular}

\section{Sensitivity of Staphylococcus aureus to penicillin} under anaerobic growth conditions

Three drops of broth containing 5, 300 and 15,000 viable cells respectively were placed on each of a duplicate series of agar plates containing $\mathbf{0} \cdot \mathbf{2}, \mathbf{0} \cdot \mathbf{1}$, $0.05,0.025,0.012,0.06,0.03$ and 0 unit penicillin $/ \mathrm{ml}$. One series was incubated aerobically and the other anaerobically in a McIntosh and Fildes jar at $37^{\circ}$. Although growth was slower and the final size of colony was smaller with anaerobic growth, there was no difference in the number of colonies after 16 and $64 \mathrm{hr}$. which appeared at each concentration whether grown with or without air. Thus the initial site of penicillin action cannot be concerned with the metabolism of oxygen as such.

\section{Increase of bound penicillin during growth}

Provided that no growth occurs in the presence of penicillin, the penicillinbinding capacity of cells is the same whether they are harvested during the logarithmic phase of growth (Fig. 4) or during the stationary phase, or washed with distilled water and suspended in neutral buffer, namely $0 \cdot 9 \pm 0 \cdot 1$ unit/g. dry wt. However, when the cells were grown in the presence of penicillin the uptake progressively increased to approximately double after about $30 \mathrm{~min}$. Previous experiments (Cooper, 1954) showed that resting cells contained a reserve of 
$\mathrm{PBC}$, liberated by rupture, which is approximately equal to the $\mathrm{PBC}$ available to penicillin in the intact cell. Thus such cells actually contain twice as much PBC as they appear to in the intact state. From Fig. 4, allowing for this reserve $\mathrm{PBC}$, the total rate of synthesis of $\mathrm{PBC}$ in the control culture is about $\mathbf{2 . 5}$ units/l. of culture/100 min., whereas the rate of exposure of $\mathrm{PBC}$ during the first $30 \mathrm{~min}$. after addition of penicillin is about $\mathbf{1 0 \cdot 2}$ units/l. of culture/ $100 \mathrm{~min}$. Therefore, either the rate of synthesis is greatly stimulated by penicillin, or else the $50 \%$ of the total $\mathrm{PBC}$ which is held in reserve is rapidly mobilized and exposed to penicillin, while synthesis continues at the normal rate. The latter view is rendered more likely by the finding that, when cells were grown for $60 \mathrm{~min}$. in presence of 0.1 unit non-radioactive penicillin $/ \mathrm{ml}$,,

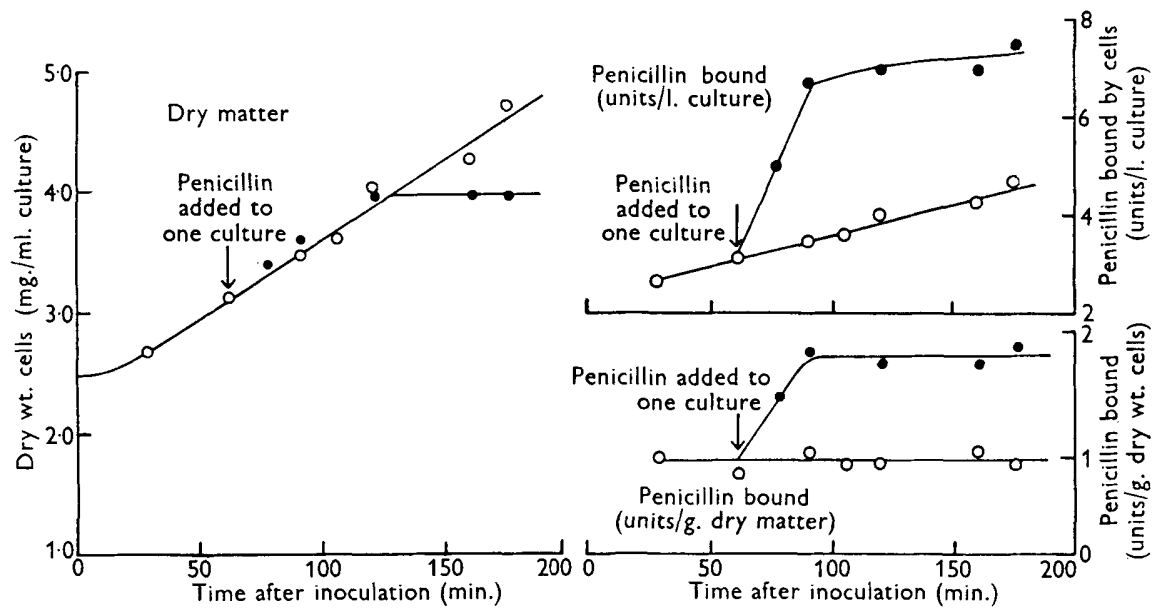

Fig. 4. Penicillin binding by Staphylococcus aureus in the growing phase. Cells added equivalent to $2.5 \mathrm{mg}$. dry wt. $/ \mathrm{ml} .(\mathrm{O}-\mathrm{O})=$ control culture, samples $(10 \mathrm{ml}$.) of the culture taken at intervals were mixed with cold radiopenicillin to give 0.1 unit penicillin/ml. Growth was stopped within $1 \mathrm{~min}$. by cooling. $(\bullet-\bullet)=$ penicillintreated culture, radiopenicillin added to the culture to $0.1 \mathrm{unit} / \mathrm{ml}$ at $60 \mathrm{~min}$. Growth was allowed to proceed in presence of penicillin, samples being taken at intervals and rapidly cooled. Both sets of samples were then washed before ${ }^{35} \mathrm{~S}$ assay and measurement of dry wt. cells $/ \mathrm{ml}$.

washed three times with distilled water and ruptured, the radiopenicillinbinding capacity of the lipid particles was decreased from 12 units/g. (control) to 1.8 units/g. Contact of the intact cells with 0.1 unit non-radioactive penicillin $/ \mathrm{ml}$. without growth only decreased the uptake to 6 units $/ g$. Thus, at least $70 \%$ of the reserve $\mathrm{PBC}$ had been exposed to penicillin during growth, the remaining small uptake by the lipid particles possibly being due to some PBC synthesized during this period of growth and not yet exposed to penicillin. The reserve $\mathrm{PBC}$ can be rapidly exposed by mechanical rupture at $2^{\circ}$ in presence of $1 \%$ formalin when enzymic synthesis would be much slowed, so that exposure without synthesis seems quite possible. Some synthesis of PBC may continue for a time after exposure of the reserve $\mathrm{PBC}$ is largely complete 
(Fig. 4). Eagle (1954) was unable to find any significant effect of the metabolic state of bacteria on their ability to bind penicillin, but the increase in uptake on growth found by Cooper \& Rowley (1949) and by Few, Cooper \& Rowley (1952), was also observed by Maass \& Johnson (1949b).

\section{DISCUSSION}

So far from the osmotic barrier of Gram-positive bacteria being merely a semipermeable dialyzing membrane which retains large but not small molecules, it is impermeable to phosphate (Mitchell, 1953) while allowing free entry of lysine, (Gale, 1947). The cell is, therefore, obliged to assimilate phosphate by transport mechanisms requiring energy. Little is yet known of the bacterial uptake mechanisms for other elements or water. It may not be sufficient, however, to assume that all positive ions enter merely by diffusion as 'gegenions', as certain authors have invoked active mechanisms for $\mathrm{K}^{+}$transport into erythrocytes (e.g. Ponder, 1950; Harris \& Maizels, 1952). Also sheep kidney cortex mitochondria may assimilate $\mathrm{Mg}^{++}, \mathrm{PO}_{4}^{m}, \mathrm{~K}+$ and $\mathrm{Na}^{+}$by processes which require energy (e.g. Bartley \& Davies, 1954).

Effects of penicillin on properties of the osmotic barrier. The association of PBC with cell-wall lipoprotein suggests that penicillin may initially disorganize some function of the osmotic barrier (Cooper, 1954). The glutamate assimilation is unaffected until about $60 \mathrm{~min}$. after addition of penicillin (Gale \& Taylor, 1947) when it is suddenly very seriously impaired, but it is not at present certain whether, as seemed likely earlier, the uptake of glutamate is in fact by active transport mechanisms (Gale, 1953). The present work shows that at least one active mechanism, namely phosphate assimilation, abruptly ceases to function at about the same time, even if its inactivation is not irreversible. It might also be inferred from the sudden stoppage of increase of dry matter soon after, while the cell can still probably synthesize peptides or proteins, deoxyribonucleic acid and ribonucleotides from internal resources (Gale \& Taylor, 1947; Hotchkiss, 1950; Gale \& Paine, 1951; Gros \& Macheboeuf, 1953; Mitchell \& Moyle, 1951 $a$; present work), that the replication of the bulk of cell material (carbon and nitrogen compounds) is blocked at the stage of taking into the cell. The time course of the impairment of $\mathbf{K}^{+}$, $\mathrm{Na}^{+}$and $\mathrm{Mg}^{++}$uptake closely resembles that of dry matter and $\mathbf{P}$, but it remains to be seen whether these metals enter by active or passive transport mechanisms. If passive, then uptake cessation is due to prevention of synthesis or uptake of their several receptors (not peptides, certain large molecule phosphates, or glucose oxidation products), and is not a direct result of impairment of osmotic barrier function. Nevertheless, whether or not these changes represent a general impairment of the active functions of the osmotic barrier, it is evident that they take some time to appear, so that they probably represent secondary effects of penicillin. Certain properties such as retention of solutes, and possibly exclusion of water, are also not affected until somewhat later, so that breakage of the osmotic barrier is not an early effect of penicillin either. This is possibly reflected in the unaffected synthesis of lipid phosphates 
and the lipid particle fraction when the organism is grown in the presence of penicillin.

Later secondary effects of penicillin. Meanwhile, respiration, fermentation and oxidation of glucose, and lysine uptake (Gale \& Taylor, 1947; Gros \& Macheboeuf, 1953) continue with peptide and nucleic acid synthesis, although the nucleoide-oxidizing ability is considerably impaired by the time that turbidity reaches its peak. In view of the probable drop in internal $\mathrm{pH}$ value due to depletion of alkali metals while respiration continues and the increase in osmotic permeability, it is in fact surprising that more enzyme deficiencies have not been noticed, particularly those involving $\mathbf{M g}$ and $\mathbf{P}$. As the glutamate assimilation system appears to require $\mathbf{M g}$ or $\mathbf{M n}$ for its energy supply (Gale, 1949), the deficiency of $\mathrm{Mg}$ may be the cause of its impaired function. Also $\mathrm{K}^{+}$stimulates uptake of glutamic acid by Staphylococcus aureus (Davies, Folkes, Gale \& Bigger, 1953).

Deficiency of certain elements may also account for another effect of penicillin. The cellular acid-soluble ribonucleotides increase very markedly on growth with penicillin, while RNA remains steady (Park, $1952 a-c, 0.1$ unit penicillin/ml.; Mitchell \& Moyle, 1951 $a, 1 \mu \mathrm{g}$. penicillin $/ \mathrm{ml}$.) and this could be interpreted as a block in RNA synthesis at the stage of nucleotide polymerization. Synthesis of DNA is apparently unaffected. The present work shows that the use of $3 \%$ phenol to liberate the small molecular components of the cell did not reveal any accumulation of soluble nucleotides after addition of penicillin. On the contrary, large molecule $\mathbf{P}$ synthesis continued at the expense of the pool of phenol-soluble organic phosphorus. It is, therefore, suggested that penicillin allows ribonucleotides to enter RNA normally for a time, but the cell's elementary deficiencies somehow weaken this RNA synthesis, so that the more recently added ribonucleotides are removed by the rather drastic treatment with trichloroacetic acid. The RNA isolated from Gram-positive cells contained about $5 \%$ firmly bound Mg (Henry \& Stacey, 1946) and $\mathrm{Mg}$ is essential in considerable amounts for Gram-positive cells (Webb, 1951). Absence of Mg decreases the rate of RNA synthesis to onetenth in Escherichia coli (Abelson \& Aldous, 1950), but it is not known at present what role if any metallic elements play in nucleic acid structure. It is interesting that the giant forms induced by deficiency of $\mathrm{Mg}$ (Webb, 1951) are similar to those formed in sub-lethal penicillin concentrations (Fleming, Voureka, Kramer \& Hughes, 1950), although it is true that other substances besides penicillin can induce giant forms.

The nature of the reaction controlled by $P B C$. The exact nature of this reaction is still not known; none of the characters examined was damaged very soon after adding 0.1 unit penicillin $/ \mathrm{ml}$. It is tempting to speculate that the increase of bound penicillin caused only by growth in the presence of penicillin is the result of the forced substitution of the normal substrate of PBC by penicillin. Thus the obscured half of the total PBC may be progressively diverted by penicillin from duties which involve it in a routine cycle, and the rate of $\mathrm{PBC}$ release (above that due to its normal synthesis) would represent the normal rate of turnover of $\mathrm{PBC}$ when metabolizing its substrate. If so, it 
can be calculated from this rate and from the rate of increase of dry matter (Fig. 4) that the 'free' PBC turns over about ten times in order to double the cell mass. Each cell will bind $\mathbf{3 0 0}$ molecules of penicillin, and if $\mathbf{1}$ molecule of penicillin displaces 1 molecule of PBC substrate, then in order to produce two cells from one, PBC would metabolize 3000 molecules of substrate-the amount of substrate required by one cell. Several assumptions are involved here, but even if this rough calculation is ten times too low, then a quantitative change in a reaction of such a small size would still require a very specific analytical method to detect it.

On the bases of (1) the effectiveness of penicillin in the absence of all organic matter other than glucose, and in the absence of air, and (2) the likelihood that above 0.1 unit penicillin $/ \mathrm{ml}$. the use of PBC is completely stopped either immediately penicillin is added (as all free $\mathrm{PBC}$ is bound within $\mathbf{2 - 3}$ min. or at least by the time of the earliest observed abnormality-i.e. block in $\mathrm{Na}$ uptake, $20-30 \mathrm{~min}$.), it is possible to say what are not functions of $\mathbf{P B C}$, namely: gross assimilation of oxygen, $\mathrm{Na}, \mathrm{Mg}, \mathrm{K}, \mathrm{P}, \mathrm{Fe}, \mathrm{Co}$, or material contributing largely to the dry matter, including all organic substances; synthesis of the major part of lipid phosphates and the lipid particle fraction. The very small turnover rate of $\mathrm{PBC}$ deduced above would also exclude uptake of $\mathrm{Ca}$, and synthesis of the major part of fractions present in large amount such as PGP, DNA, RNA, cell wall material and proteins, although synthesis of a minor component of these fractions would be possible but difficult to detect. It is also possible that $\mathrm{PBC}$ is the shuttle mechanism for the intake of a trace element required in amounts similar to those of cobalt, although if this be so the shuttle is not actuated by thermal agitation as is that for phosphate (Mitchell, 1953), since no turnover of PBC occurs in the resting state.

In conclusion, it may be said that although penicillin is bound by a component very close to the osmotic barrier and most of the earliest large-scale changes have some connexion with active properties of the cell wall, yet these changes do not begin with this organism until at least 20-30 min. after addition of penicillin under conditions where the initial lesion should be evident at once. It remains to be seen what is the function of the system initially affected by penicillin, and how this small defect causes damage to certain cell wall activities while other metabolic activities continue.

I am indebted to Dr D. Rowley for his invaluable criticism and support. I am also grateful to the Central Research Fund, London University, for a grant for apparatus, and to Mr Garton, of the Ministry of Supply, Woolwich Arsenal, for some spectrographic assays of cobalt.

\section{REFERENCES}

Abelson, P. H. \& Aldous, E. (1950). Effects of magnesium on phosphate metabolism in vivo. Fed. Proc. 9, 143.

Bartley, W. \& Davies, R. E. (1954). Active transport of ions by subcellular particles. Biochem. J. 57, 37.

Cooper, P. D. (1954). The association of the penicillin-binding component of Staphylococcus aureus with a lipid fraction. J. gen. Microbiol. 10, 236. 
Cooper, P. D., Clowes, R. C. \& Rowsey, D. (1954). A note on the use of radioactive penicillin. J. gen. Microbiol. 10, 246.

Cooper, P. D. \& Rowley, D. (1949). Investigations with radioactive penicillin. Nature, Lond. 163, 480.

Davies, R., Folkes, J. P., Gale, E. F. \& Bigger, L. C. (1953). The assimilation of amino acids by micro-organisms. 16. Changes in sodium and potassium accompanying the accumulation of glutamic acid or lysine by bacteria and yeast. Biochem. J. 54, 430.

EAGLE, H. (1951). Further observations on the zone phenomenon in the bactericidal action of penicillin. J. Bact. 62, 663 .

Eagle, H. (1954). The binding of penicillin in relation to its cytotoxic action. I. Correlation between the penicillin sensitivity and combining activity of intact bacteria and cell-free extracts. J. exp. Med. 99, 207.

Few, A. V., Cooper, P. D. \& Rowley, D. (1952). Reaction of penicillin with the staphylococcal cell wall. Nature, Lond. 169, 283.

Fiske, C. H. \& SubbaRow, Y. (1925). The colorimetric determination of phosphorus. J. biol. Chem. 66, 375.

Fleming, A., Voureka, A., Kramer, I. R. H. \& Hughes, W. H. (1950). The morphology and motility of Proteus vulgaris and other organisms cultured in the presence of penicillin. J. gen. Microbiol. 4, 257.

GALE, E. F. (1947). The assimilation of amino acids by bacteria. I. The passage of certain amino acids across the cell wall and their concentration in the internal environment of Streptococcus faecalis. J. gen. Microbiol. $1,53$.

GaLe, E. F. (1949). The assimilation of amino acids by bacteria. 8. Trace metals in glutamic acid assimilation and their inactivation by 8 -hydroxyquinoline. J. gen. Microbiol. 3, 369.

Gale, E. F. (1953). Assimilation of amino acids by Gram-positive bacteria and some actions of antibiotics thereon. Advanc. Protein Chem. 8, 285.

Gale, E. F. \& Paine, T. F. (1951). The assimilation of amino acids by bacteria. 12. The action of inhibitors and antibiotics on the accumulation of free glutamic acid and the formation of combined glutamate in Staphylococcus aureus. Biochem. $J .48,298$.

GALE, E. F. \& TAYLOR, E. S. (1947). The assimilation of amino acids by bacteria. 5. The action of penicillin in preventing the assimilation of glutamic acid by Staphylococcus aureus. J. gen. Microbiol. 1, 314.

Grelet, N. (1949). Activité comparée de la pénicilline sur la croissance de Bacillus subtilis en milieu synthétique ammoniacal et en milieu peptoné. Ann. Inst. Pasteur, 77, 263.

Gros, F. \& Macheboeuf, M. (1953). Metabolisme de l'acide ribonucléique et de la guanosine chez Staphylococcus aureus et Escherichia coli traités par la pénicilline pendant leur croissance. Symp. VIth Int. Congr. Microbiol., Growth Inhibition and Chemotherapy, p. 38.

Harris, E. J. \& MaIzels, M. (1952). Distribution of ions in suspensions of human erythrocytes. J. Physiol. 118, 40.

Henry, H. \& Stacey, M. (1946). Histochemistry of the Gram-staining reaction for micro-organisms. Proc. Roy. Soc. B, 133, 391.

Hoтchкiss, R. D. (1950). The abnormal course of bacterial protein synthesis in the presence of penicillin. J. exp. Med. 91, 351 .

Hunter, T. H. \& BAKER, K. T. (1949). The action of penicillin on Bacillus subtilis growing in the absence of amino acids. Science, 110, 423.

Kapuscinski, V., Moss, N., ZaK, B. \& Boyle, A. J. (1952). Quantitative determination of $\mathrm{Ca}$ and $\mathrm{Mg}$ in human serum by flame photometry. Amer. J. clin. Path. 22, 287.

MaAss, E. A. \& Johnson, M. J. (1949a). Penicillin uptake by bacterial cells. J. Bact. 57, 415. 
MaAss, E. A. \& Johnson, M. J. (1949b). Relation between bound penicillin and growth in Staphylococcus aureus. J. Bact. 58, 361.

Miles, A. A. \& Mrsra, S. S. (1938). The estimation of the bactericidal power of the blood. J. Hyg., Camb. 38, 732.

Mitchell, P. (1953). Transport of phosphate across the surface of Micrococcus pyogenes: nature of the cell 'inorganic phosphate'. J. gen. Microbiol. 9, 273.

Mrtcheld, P. \& Moyle, J. (1950). Occurrence of a phosphoric ester in certain bacteria: its relation to Gram-staining and penicillin sensitivity. Nature, Lond. 166, 218.

Mitchell, P. \& Moyle, J. (1951a). Relationships between cell growth, surface properties and nucleic acid production in normal and penicillin-treated $M$. pyogenes. J. gen. Microbiol. 5, 421.

Mitchell, P. \& Moyle, J. (1951 b). Isolation of hydrolytic products of a glycerophospho compound from Micrococcus pyogenes. J. gen. Microbiol. 5, 966.

Mrtchell, P. \& Moyle, J. (1953). Paths of phosphate transfer in Micrococcus pyogenes: phosphate turnover in nucleic acids and other fractions. J. gen. Microbiol. 9, 257.

PARK, J. T. (1951). The uridine-5' $\mathbf{5}^{\prime}$-pyrophosphate compounds found in penicillintreated Staphylococcus aureus cells. A Symposium on Phosphorus Metabolism, 1, 93. Baltimore, Md.: Johns Hopkins University Press.

PARK, J. T. (1952a). Uridine-5'-pyrophosphate derivatives. I. Isolation from Staphylococcus aureus. J. biol. Chem. 194, 877.

PARK, J. T. (1952b). Uridine-5'-pyrophosphate derivatives. II. A structure common to three derivatives. J. biol. Chem. 194, 885.

PARK, J. T. (1952c). Uridine-5'-pyrophosphate derivatives. III. Amino acidcontaining derivatives. J. biol. Chem. 194, 897.

Parker, R. F. \& Marsh, H. C. (1946). The action of penicillin on staphylococcus. J. Bact. 51, 181.

Ponder, E. (1950). Accumulation of potassium by human red cells. J. gen. Physiol. $33,745$.

Rowley, D., Cooper, P. D., Roberts, P. W. \& Lester Smith, E. (1950). The site of action of penicillin. 1. Uptake of penicillin by bacteria. Biochem. J. 46, 157 .

WeBb, M. (1951). The influence of magnesium on the growth of bacteria in chemically-defined media of varying complexity. J. gen. Microbiol. 5, 485.

(Received 3 September 1954) 